\title{
THE HISTORY OF THE RAILWAY BRIDGES BY THE CITADEL IN WARSAW
}

\author{
T. BLADYNIEC ${ }^{1}$
}

\begin{abstract}
In 1875 a steel railway bridge was built in northern Warsaw. It had seven spans of $66.22 \mathrm{~m}$ and two spans of $15.24 \mathrm{~m}$. In 1908 the second railway bridge was built downstream of the older one. The spacing of supports and spans were the same as in the older bridge. During World War I, both bridges were blown up and then rebuilt, first temporarily and then permanently. Again both were blown up in 1944. In 1945, a temporary crossing was built. In 1947 a permanent bridge was rebuilt, partially replacing rivets with welding. On the pillars of the older bridge, the Gdański Bridge was built (not in this study). In 1963 welded connections were strengthened, in 1980 the structure of the northern track was replaced. In 2016, the northern track was renovated. The replacement of the structure of the southern track is ongoing since 2018 .
\end{abstract}

Keywords: bridges, Citadel, destruction, history, reconstruction, steel, truss, Warsaw;

\section{INTRODUCTION}

Railway bridges by the Citadel have had fundamental strategic and communication importance for Warsaw and administrators of the lands in which the city was located. Due to this fact these bridges were usually the first victims of the armed conflicts, but also were the first ones to reconstruct after post-war damages.

Necessity to build a railway bridge by the Citadel resulted from the specific character of a transport junction which has been formed in Warsaw. In XIX century Warsaw was the end station for many separate railroads coming from different directions and what is more, of different rail gauges. Warsaw

\footnotetext{
${ }^{1}$ MSc., Eng., e-mail: tomasz.bladyniec@gmail.com
} 
- Vienna Railway approaching the city from the West had standard track gauge of $1435 \mathrm{~mm}$, while all other railways located on the right bank of Vistula had the wide gauge, typical for the Russian Empire. Over the period 1865-1867, on the initiative of the association founded by Leopold Kronenberg, was built $205 \mathrm{~km}$-long line Warsaw - Terespol of the wide tracks.

It has become clear that railways in Warsaw require to be connected in one single system. Also, Russian military wanted to have a possibility to transport quickly over Vistula. In 1873 Russian authorities decided to build a Ring Railway connecting the following railways: Warsaw - Vienna, Warsaw - Petersburg and Warsaw - Terespol. The project was commissioned to Tadeusz Chrzanowski. The Ring Railway was over $17 \mathrm{~km}$ long and run around the city from the West and North. It was planned mostly because of strategic and military reasons, but also included local civil needs.

\section{THE BRIDGE FROM 1875}

Construction of the Ring Railway meant the need to design and to implement a new and big permanent crossing over the Vistula. At that time there was only one bridge in Warsaw, officially called Aleksandrowski Bridge (pol. Most Aleksandrowski; commonly named Kierbedzia Bridge, pol. Most Kierbedzia). Usually train bridges in that period were designed with flanking towers to defend it in case of war. However, the new bridge has been located in close vicinity of the Citadel fortress and it was fully covered by its artillery, so the military authorities decided to resign from the towers.

\subsection{DESIGN}

Due to the guidelines provided by the Ministry of Communication, the designer had to create the construction of the American type, meaning parallel lines and cross-bracing truss. New crossing was supposed to count 7 simply supported truss spans of $66.22 \mathrm{~m}$ of support spread and two short spans of plate structure and spread of $15.24 \mathrm{~m}$ each.

The designer was Tadeusz Chrzanowski (1822-1892). He graduated from the Institute of Communication Engineers in St. Petersburg. Later he was an assistant to Smolikowski on the construction site of Aleksandrowski (Kierbedź) Bridge in Warsaw. In 1862, he became the main constructor of this bridge and in the following year he became the inspector of the Warsaw Communication District. In 1866 he was appointed technical director of the WarsawskoTerespolska iron road construction. In the years 1867-1868 he managed the construction of the bridge through the Bug near Terespol and became its director after completion. 
Chrzanowski applied his own theory to calculate the forces in cross-bracing of the truss. By applying in it a sectional steel the truss was looser then in constructions built so far. The bridge girders were $6.02 \mathrm{~m}$ high and had $5.18 \mathrm{~m}$ of spacing. The crossing was two-levels. Its upper part was provided for the rail traffic and had designed single, special track of four rails called combined track. Such solution allowed to use it both by regular-track trains of $1435 \mathrm{~mm}$ gauge and wide track of $1524 \mathrm{~mm}$ gauge. The full width of the track on the bridge was $1962 \mathrm{~mm}$. This solution was required because the entire Ring Railroad provided the traffic of trains of both gauges. The lower part of the bridge was planned for vehicular and pedestrian traffic, therefore the carriageway was designed there. The carriageway was intended to have solely military purposes - to transport artillery and other equipment.

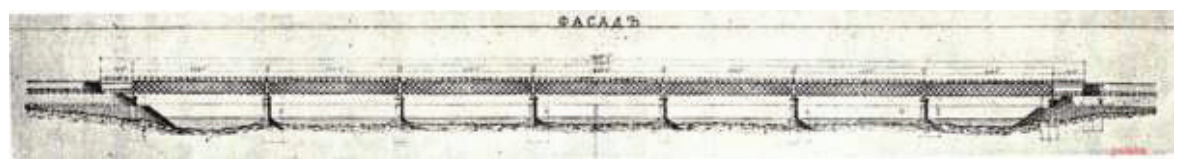

Fig. 1. Design of the bridge by Tadeusz Chrzanowski: 7 cross-bracing truss spans of $66.22 \mathrm{~m}+2$ plate structure spans of $15.24 \mathrm{~m}$ each.

\subsection{Construction}

Construction of the bridge started at the end of April 1873. Works on the site were carried out by the firm Przemysłowe Towarzystwo Akcyjne Lilpop, Rau i Loewenstein. With regard to the construction, the Citadel headquarters installed a temporary pontoon bridge on the South direction from the designed bridge. The superstructure was made of the cast steel brought from England. Steel plate was coming from Belgium, cement from England and material for siding of the supports - granite - from Sweden. Both the abutment on the right side of the Vistula and all pillars were founded on the steel caissons; just the left-bank abutment was founded directly on the ground. It was the first case in history when in the Polish lands the caissons were lowered by Polish technical forces. The depth of theirs lowering was no less than $12 \mathrm{~m}$ below the Vistula "zero" point. In spring 1874, during the lowering of one of the caissons of the size $4.5 \times 14 \mathrm{~m}$, occurred accident. The caisson that was being lowered on the chains from the scaffolding broke loose and was carried away by the stream down the river. The decision was to drop it and to lower the second caisson. At the end of May of the same year occurred the second accident. As result of heavy rains there was a flood on Vistula which caused damage manifested in numerous remains of houses, rafts, trees and livestock flowing through the city. The items carried by the stream accumulated before the scaffolding of the bridge being constructed. On this scaffolding was standing not installed yet a steel span of the 
bridge. Despite the fact it was already fixed to the supports, the span was carried away by the pushing rafts, fell to the water and being hold by the supports, broke down. It was necessary to pull it out from the river, replace damaged parts and straighten the bent ones.

Until autumn of the same year the construction of the five pillars was completed and works over the sixth one were coming to the end; there were carried out works involving installation of the four spans. Basic works in the construction of the bridge were finished until the beginning of February 1875, and in July the bridge was used by the trains transporting sand from Targowek for the construction of left-bank part of the Ring Railroad. On 19 November 1875 took place the formal acceptance of the bridge by the railway authorities. One year later, on 14 November, was put in use the whole Ring Railway. Upon termination of the works at the bridge the pontoon bridge was removed.

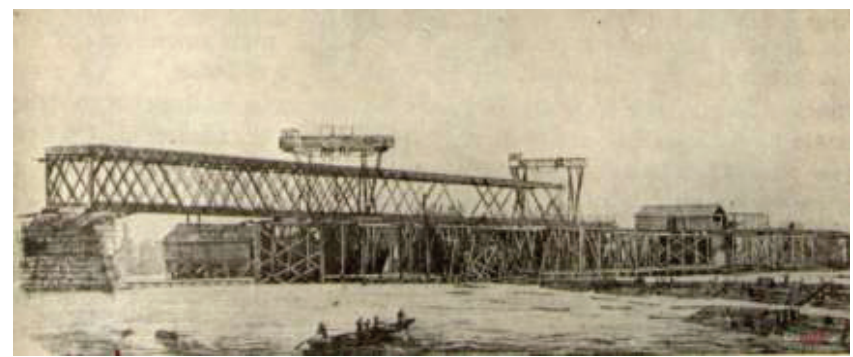

Fig. 2. Construction of the bridge in 1874. Visible two portal cranes built on the site were used for movement and installation of the steel structure.

\section{THE BRIDGE FROM 1908}

Rail traffic going through the bridge by the Citadel was increasing and on the turn of the centuries reached the number of 114 trains per day. Because it was designed with regard to locomotives with axle load of 13 tons, the new type steam locomotive of axle load of 20 tones could not use it. Therefore there was taken a decision to build another railway bridge near the Citadel, located in the direct vicinity of the first one, and also to rebuild the existing one with purpose to increase its load capacity.

\subsection{DESIGN}

Designed new bridge was supposed to be located $21.34 \mathrm{~m}$ below the old one and such solution was to be similar to the previous crossing - on the upper part was supposed to run a combined track and 
the lower part was to be used by the vehicular traffic. In the same time for the old bridge was planned a replacement of the superstructure for the identical like in the new one. In result there would be obtained two twin, closely located bridges, where each of them would serve one direction. Development of the plans was commissioned to professor Bielelubski in Petersburg. The direct designer of the new bridge was Aleksander Pstrokoński (1859-1951). He graduated in 1885 from the Institute of Communication Engineers in St. Petersburg, worked on the railway, in the Technical Board of the Ministry of Communications of Russia. He was preparing projects of bridges - with prof. Bielelubski and by himself. In the years 1919-1926 he worked in the technical department of the Directorate of State Railways Construction in Warsaw, where he designed bridges and other railway facilities. During World War II he was in Warsaw, later he went to Tarnow.

New double-track railway bridge was located in $32 \mathrm{~km}$ of downstream with respect to the old one. Its pillars were placed within the old axis and thanks to this fact the completion of the ice-breakers was not necessary and all the spans were the same like in the previous crossing. The superstructure was composed of two simply supported steel truss girders. The girders were separate for each track, however they were laid on the shared supports. Upper and lower chords of the truss were concurrent towards each other; theirs spread was $3.42 \mathrm{~m}$ and the height $6 \mathrm{~m}$, the same like in the old bridge. The traffic was supposed to operate on the upper part of the girders, on each of them was to laid one combined track composed of the four rails. Thanks to the same composition of supports, spread and height of spans, the two bridges were supposed to harmonize visually.

\subsection{Construction}

Construction works started just on the beginning of January of 1905. With respect to construction of the supports there was built a side-track for the transport of materials from Praga Nadwiślańska station. For construction works purposes there was also used the lower deck of the adjacent bridge. The deck was closed for the traffic, was laid there service railway and the cable with compressed air, water and power coming from located on the right bank engine room. The material was transported by the narrow-gauge train and then carried by ramps to the place of its incorporation. Such solution prevented from construction of the working bridge. The site counted 200 workers.

The abutments of the bride were founded in piles and the intermediate supports in steel caissons designed to a depth from 14.95 to $19.20 \mathrm{~m}$ below the zero of the Vistula. Three caissons were lowered in the same time. First one, located most closely to the right bank started to be lowered on 30 June and finished on 20 August 1905. During the lowering of the second one occurred difficulties - it was encountered the old caisson from the construction of the previous bridge. Became necessary to cut it 
into pieces and remove it outside via working sluices. All the four pillars and abutment on the right side bank were nearly ready in the middle of December 1905.

From the outside the supports were covered by grey granite taken from Volhynia, and from the sides - by facings produced in situ from fieldstones. Installation of the spans was carried out from June 1907 to February 1908. The bridge was tested only in July of the same year.

The new railway bridge was opened for the traffic in August 1908. Initially was used only by the wide-gauge trains, while the normal-gauge trains were using the old bridge. It was related to the fact that under the railway traffic was executing the construction of the brick viaduct on the Ring Railway along Zakroczymska Street. In the second part of November of the same year all the railway traffic was moved to the new bridge (both wide and normal gauges), however until August 1909 happened, that some of trains were allowed to travel through the old bridge. After moving the railway traffic to the new bridge, Warsaw Municipality exchanged the wooden beams on the lower level of the old bridge and in 1910 opened it for the vehicular traffic. For over 10 another years the lower level was used by wagons and sporadically by pedestrians, while the upper level was not used.

\section{SITUATION OF THE BRIDGES DURING THE WORLD WAR I}

On the beginning of May 1915 the German and Austrian armies launched an offensive against the Russian forces. In summer the German forces approached Warsaw. On the order of Russian general Schwartz on 2 August 1915 all the bridges over the Vistula were mined. On 5 August, around 7 a.m. both bridges by the Citadel were blown up by the Russian military. In the bridge from the period 1873-1875 the Russians blown up: second pillar from the side of the left bank and the girder of the next (fourth) span. In result three spans were damaged. In the new bridge there were blown up fourth and sixth pillar counting from the left bank. Third and fourth span completely slid down to the water. Fifth and sixth span remained by one end with slight displacements in the pillars, each track had its own pair of girders supported on shared pillars therefore the damages in both tracks were the same. Railway bridges by the Citadel had a strategic importance and the Germans took decision to rebuild them using their own funds. Despite the fact that they started to rebuild the bridges immediately after taking over Warsaw, they expected that these works would take relatively lot of time. Therefore they took decision to run a temporary ferry.

The construction works on the bridges started on 8 August, three days after the Germans marched into Warsaw. Works had provisional nature. As the first one was brought back to service the North track of the bridge from the period $1905-1908$. Third and fourth span were elevated up to the height 
over high water and were supported by the intermediate supports. And the fifth and sixth span were elevated up to the original level and were supported by the cages. Theirs elevation on the height of 9 meters took 8 days. To achieve equal level of the passing part of the bridge on its whole length, on the third and fourth span were build wooden construction of $3 \mathrm{~m}$ height. Already on 1st September of the same year over rebuilt track drove towards East the first German train with military transportation, what was one of the records during the World War I. Similarly engineering - railway military troops reconstructed the South track, which was put into use on 17 September. Finishing works carried out by one of the company lasted until 1st October.

The Germans also took decision of temporary reconstruction of the bridge from the period 1873 1875 with regard to its use as the substitute railway bridge in case of renovation of the tracks on the newer bridge. Damaged spans were not removed from the river, the piles were driven between spans' elements. As result the supports were places irregularly. Three damaged spans were replaced by 12 steel plate girders on the intermediate supports. Works were finished on 23 September 1915. The company J. Gollnow und Sohn from Stettin received commission for permanent reconstruction of the both bridges by the Citadel. Works on the south track of the newer bridge lasted from 30 September 1915 to 22 January 1916, when the bridge was put into service. During that time the traffic railway was directed to the older bridge. While completing construction works on the newer bridge were, among others, complemented with concrete the blown up pillars. Permanent reconstruction of the North track was finished on 19 February 1916. In practice 350 workers were engaged in the project, mostly local Polish men.

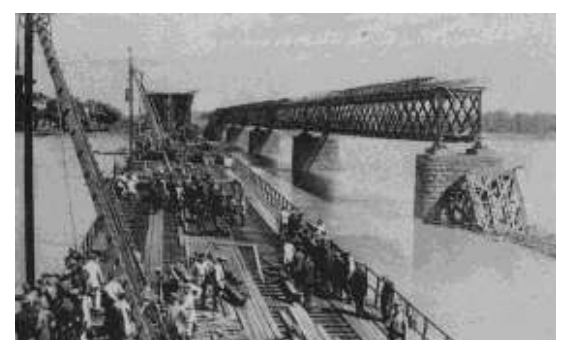

Fig. 3. Reconstruction of the newer bridge by the Germans during the World War I. Damaged older bridge visible on the right.

Reconstruction of the older bridge started just after termination of works on the newer bridge and was finished in April 1916. Three damaged spans were cut for scrap and removed, and in their place was built the new construction composed of the same girders like in the newer bridge. 


\section{THE INTERWAR PERIOD (1918-1939)}

In the moment of gaining independence by Second Polish Republic the older bridge by the Citadel on the upper level had railway surface and on the lower one narrow carriageway permitting onesided vehicular traffic. During the Polish-Soviet war in summer 1920, the decision was made to rebuild the bridge with purpose to enable Polish army evacuation to the left side of the Vistula. In that time the Warsaw bridges were administrated by Bronisław Plebiński. He and his personnel within 10 days managed to dissemble the track on the upper level and build there a wooden deck together with access.

\section{THE WORLD WAR II}

During September Campaign of 1939 the bridges in Warsaw were not blown up. However they were, to a various degree, damaged as the result of the course of acts of war. The older bridge by the Citadel, that time serving as the urban road bridge, had 21 large damages in the steel construction, and also in the sidewalks and the guardrails. By order of Nazi authorities in occupation, the bridge was renovated and later, in the period 1940 - 1941, remade again to a railway bridge. That time were built cross braces between upper and lower level, as result of what the pedestrian traffic on the lower side was already impossible. Also the new bridge by the Citadel was damaged in 1939. Renovation of this bridge was executed by German Eisenbahn Verkehrsamt. After the outbreak of the Warsaw Uprising on 1st August 1944, the Germans filled all the bridges on the Vistula preventing communication between right and the left-bank part of the city. On 13 September 1944, a day before the Red Army walked into Praga district, the Nazis blew up all the Warsaw crossings. Both bridges by the Citadel were blown up in the afternoon.

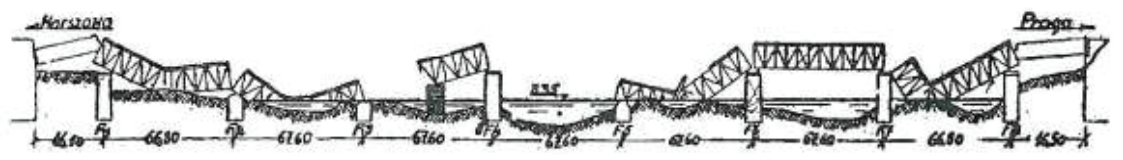

Fig. 4. Scheme of destroyed railway bridge. Almost all girders and supports have been damaged. 


\section{TEMPORARY RAILWAY BRIDGE FROM THE PERIOD 1945-1947}

After taking over Warsaw by the Red Army started the construction of temporary bridges. In 18 January 1945 Red Army engineering troops started the construction of a temporary railway bridge about $25 \mathrm{~m}$ above the bridges by the Citadel. This crossing was composed of 18 truss constructions with upper carriageway of support's spread $23 \mathrm{~m}$ and 2 steel plate shore spans, of $10 \mathrm{~m}$ spread. The full length of the bridge was $515.70 \mathrm{~m}$ and its height $-14.50 \mathrm{~m}$.

For this reconstruction the Soviet military prepared $3700 \mathrm{~m}^{3}$ of rounded wood, 500 wooden piles, bridge sleepers and 110 tons of metal elements for clamps, clamping rings etc. Similarly like in all Soviet war bridges, there were used intermediate wooden supports, in which, on the basis of previously driven in the bottom of the river piles, were installed wooden frames prepared ahead on the river bank. The span in the form of truss construction were transported to the site in whole, where they were put on the wooden posts with use of a bridge crane. The bridge was opened for traffic on 29 January 1945 at 17.30. It had an exceptional strategic importance, because the war was still going on and Soviets wanted to have quick transport to the West.

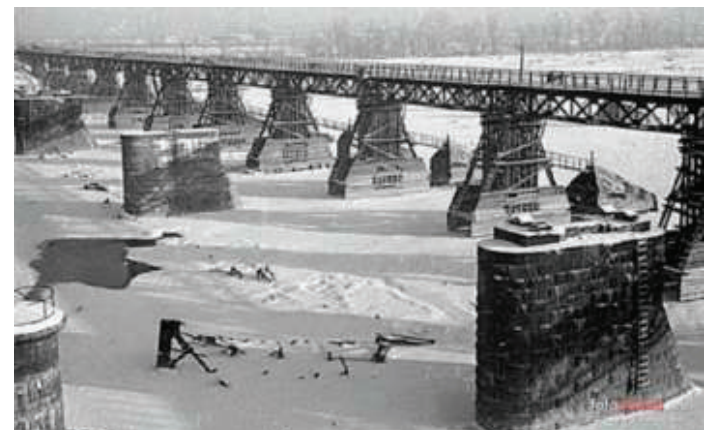

Fig. 5. Temporary bridge with visible supports of demolished railway bridges by the Citadel. Supports of the older bridge have been rebuilt just after the war, but the bridge itself was rebuilt only in $1959 \ldots$

The bridge remained until spring 1947. As result of rapid warming in March 1947 the great flood took place. On 20 March fell into the water the spans of temporary high bridge build in the centre of Warsaw. These spans together with ice floes hit the railway bridge by the Citadel which did not endure the pressure and collapsed. On the left bank remained untouched: steel plate shore span and three truss spans, and from the right side - steel plate shore span and two truss spans. Also collapsed 13 truss constructions which were found in the river - bent and silted. Part of the intermediate posts, partly damaged, were sticking out of the water. In the period from April 1947 to 
March 1948 the bridge was dissembled. Remaining girders were moved, put into wagons, the collapsed spans were pulled out from the water and cut, the remnants of wooden posts and ice breakers were demolished.

\section{POST-WAR RECONSTRUCTION AND MODERNIZATIONS}

Reconstruction of the railway bridge from 1908 took place in two stages. First was repaired the North track, by rebuilding the structure from the remains of the fallen bridge from $1907-1908$. As result was built a bridge of the same geometry like the pre-war one. For the south track were designed new girders of the same truss as the north girders with such difference, that they were welded and. The assembly of the span's superstructure started in spring 1946. On 22 July 1947 took place the opening of the south track.

In 1963 were strengthen the welds of the lower flange of the south pair of the girders of the bridge by the Citadel. In 1980 started the replacement of the north track of the bridge. Steel of the structure from 1907-1908 was already corroded, additionally the loads considerably increased. The designer kept the same geometry of the truss, but he applied closed sections of the bars, and in joints a butt welding. In design was provided application of the steel St 3M and St 35. As result was obtained significant reduction of the spans' load - the old ones weighted 264.2 tonnes each, the new ones 208 tonnes each. 6 new spans were installed on the left bank of the Vistula and in $1980-4$ new spans. Next year the last one was assembled, seventh span and 3 remaining spans were replaced. Removed old spans were transported by sapper's unit on pontoon ferries and cut into batch parts. In 2015 started modernization of the bridge aiming to increase the designed speed and loads. Until 2016 the north track was renovated. However that time the works on the south track were not continued, because the expert's analysis showed poor condition of the construction of this part of crossing. The decision to replace the spans was made. In November 2018 an agreement in scope of modernization of the south track has been signed. The works include replacement of the nine spans of the steel construction of the length over $508 \mathrm{~m}$ and the reinforcement of the supports' foundation. Two outer spans weight 10 tonnes each, remaining seven spans -27 tonnes each. After dismantle of the tracks, bridge sleepers and railway traction on the barges were put special constructions to pull down the construction from the stone supports. As result of these works the railroad on the bridge is to be adjusted to passenger train with the speed $120 \mathrm{~km} / \mathrm{k}$ and goods train with $100 \mathrm{~km} / \mathrm{h}$.

In the nearest future there is planned renovation of the cross-town railway line, what means its temporary exclusion from the operation. Then significance of the Bridge by the Citadel together 
with the whole Ring Railroad will increase extremely, because here is planned to run the trains so far using the Ring Railway.

\section{REFERENCES}

1. F. Kucharzewski: Most na Wiśle pod Warszawą zbudowany dla drogi obwodowej łączącej stacje Drogi Żelaznej Warszawsko-Wiedeńskiej i Petersbursko-Warszawskiej, „Przegląd Techniczny”, 1875 t. II, s. 336342

2. „Kurjer Warszawski”, Warszawa 1874 nr 210; 1875 nr 142; 1904 nr 361; 1905 nr 101, 178, 182, 218, 229; $1906 \mathrm{nr} 53,198 ; 1908 \mathrm{nr} 182,230,324 ; 1909 \mathrm{nr} 235 ; 1911 \mathrm{nr} 53 ; 1913 \mathrm{nr} 215$

3. „Tygodnik Ilustrowany”, Warszawa 1875 XVI s. 353

4. Opisanje mosta czerez rieku Wisłu dlja sojedinitelnoj wietwi mieżdu stancjami żelieznych dorog w gorodie Warszawie, Warszawa 1877

5. J. Eberhardt: Nowy most kolejowy na rzece Wiśle pod Warszawą, „Przegląd Techniczny” 1909, s. 1-5, 25-28

6. „Świat” Warszawa 1914, s. 2

7. Wiederherstellung der zerstörten Eisenbahnbrücke..., „Zentralblatt der Bauverwaltung” nr. 84, 20.10.1920.

8. „Życie Warszawy”, Warszawa 1945 nr 259, 316, 348; 1946 nr 105, 129

9. T. Ciszewski: Odbudowa mostu kolejowego przez Wisłę koło Cytadeli w Warszawie, zniszczonego we wrześniu 1944 r., „Przegląd Budowlany” 1946, 214-218

10. W. Sterner, "Mosty Warszawy”, Państwowe Wydawnictwa Techniczne, Warsaw, Poland, 1960

11. J. Jankowski: „Mosty w Polsce i mostowcy polscy (od czasów najdawniejszych do końca I wojny światowej)”. Wrocław: Zakład Narodowy im. Ossolińskich - Wydawnictwo, Oddział w Gdańsku, 1973, s. 346

12. Железнодорожники в Великой Отечественной войне 1941-1945 / Под ред. министра путей сообщения СССР Н. С. Конарёва — 2-е изд., доп. - М.: Транспорт, 1987. — 591 с, ил., табл.

13. B. Chwaściński, "Mosty na Wiśle i ich budowniczowie", Fundacja Rozwoju Nauki w Zakresie Inżynierii Lądowej im. A. i Z. Wasiutyńskich, Warsaw, Poland, 1997.

14. M. Czapski, A. Niemierko, J. Rymsza, "Warszawskie przeprawy mostowe przez Wisłę w ujęciu historycznym”, Fundacja Rozwoju Nauki w Zakresie Inżynierii Lądowej im. A. i Z. Wasiutyńskich, Warsaw, Poland, 2012.

15. M. Wojtczuk: "Kolejarze demontują dziewięć przęseł Mostu Gdańskiego. W operacji uczestniczą barki na Wiśle”, warszawa.gazeta.pl; 18.12.2018

\section{LIST OF FIGURES:}

Fig. 1. Design of the bridge by Tadeusz Chrzanowski (W. Sterner, "Mosty Warszawy", Państwowe Wydawnictwa Techniczne, Warsaw, 1960, p. 100)

Fig. 2. Construction of the bridge in 1874 (W. Sterner, "Mosty Warszawy", Państwowe Wydawnictwa Techniczne, Warsaw, 1960, p. 103)

Fig. 3. Reconstruction of the newer bridge by the Germans during the World War I (wikiwand.com)

Fig. 4. Scheme of destroyed railway bridge ("Przegląd Budowlany", Warsaw, 1946, p. 214)

Fig. 5. Temporary bridge with visible supports of demolished railway bridges by the Citadel (fotopolska.eu)

\section{LISTA RYSUNKÓW:}

Rys. 1. Projekt mostu autorstwa Tadeusza Chrzanowskiego (W. Sterner, "Mosty Warszawy", Państwowe Wydawnictwa Techniczne, Warszawa, 1960, p. 100)

Rys. 2. Budowa mostu w 1874 (W. Sterner, "Mosty Warszawy”, Państ. Wyd. Tech., Warszawa, 1960, p. 103)

Rys. 3. Odbudowa nowszego mostu przez Niemców w czasie I wojny światowej (wikiwand.com)

Rys. 4. Schemat zniszczonego mostu kolejowego („Przegląd Budowlany”, Warszawa 1946, s. 214)

Rys. 5. Most tymczasowy z widocznymi podporami zniszczonych mostów kolejowych pod Cytadelą (fotopolska.eu) 


\section{HiSTORIA MOSTÓW KOLEJOWYCH POD CYTADELA W WARSZAWIE}

Stowa kluczowe: most, Cytadela, zniszczenie, historia, odbudowa, stal, kratownica, Warszawa

\section{STRESZCZENIE}

W 1873 roku władze rosyjskie podjęły decyzję o budowie Linii Obwodowej łączącej linie kolejowe Warszawa Wiedeń, Warszawa - Petersburg i Warszawa - Terespol. Budowa wymagała nowej przeprawy przez Wisłę. Wybrano konstrukcję typu amerykańskiego z równoległymi pasami i krzyżulcową kratą. Nowa przeprawa miała liczyć siedem swobodnie podpartych przęseł kratownicowych po $66,22 \mathrm{~m}$ rozpiętości podporowej oraz dwóch niewielkich przęseł brzegowych o konstrukcji blachownicowej i rozpiętości po 15,24 m. Dźwigary mostu miały wysokość 6,02 m i rozstaw 5,18 m. Przeprawa była dwupoziomowa. Górną jej część przewidziano dla ruchu kolejowego z pojedynczym, specjalnym torem o czterech szynach (zespolonym). Dolna część mostu została natomiast przewidziana dla ruchu pieszego i kołowego.

Budowa rozpoczęła się w kwietniu 1873. Ustrój niosący wykonano ze stali zlewnej z Anglii. Stalowa blacha pochodziła z Belgii, cement z Anglii, a granit na oblicowanie podpór ze Szwecji. Przyczółek na prawym brzegu Wisły i wszystkie filary posadowiono na stalowych kesonach, zaś przyczółek lewobrzeżny bezpośrednio na gruncie. Zasadnicze roboty przy budowie mostu zakończono do lutego 1875. 19 listopada 1875 miał miejsce urzędowy odbiór mostu.

Ruch kolejowy przez most stopniowo wzrastał. Ponieważ był on zaprojektowany z myślą o lokomotywach o nacisku 13 ton na oś, nie mogły się nim poruszać parowozy nowego typu o nacisku 20 ton na oś. Zapadła zatem decyzja o budowie drugiego mostu kolejowego przy Cytadeli, a także o przebudowie istniejącego w celu zwiększenia jego nośności Opracowano nowy projekt. Nowy, dwutorowy most kolejowy przy Cytadeli zlokalizoano 32 m w dół rzeki względem starego. Jego filary umieszczono w osiach starych, a rozpiętości przęseł były takie jak w sąsiedniej przeprawie. Ustrój składał się w dwóch swobodnie podpartych, stalowych dźwigarów kratownicowych. Były one oddzielne dla każdego toru, spoczywały jednak na wspólnych podporach. Pasy górne i dolne kratownic były względem siebie równoległe; ich rozstaw wynosił 3,42 m, a wysokość $6 \mathrm{~m}$ - tyle samo, co w starym moście. Ruch miał odbywać się po górnej części dźwigarów. Na każdym z nich ułożone miały zostać po jednym torze zespolonym złożonym z czterech szyn.

Budowa rozpoczęła się w styczniu 1905. Przyczółki mostu posadowione były na palach, a podpory pośrednie na stalowych kesonach na głębokości od 14,95 do 19,20 m. Podpory kryte były z wierzchu granitem, a z boków - licówką wytwarzaną na miejscu z dużych kamieni polnych. Montaż przęseł odbywał się od czerwca 1907 do lutego 1908.

Nowy most kolejowy otwarto dla ruchu w sierpniu 1908. Po przeniesieniu ruchu kolejowego na nowy most Magistrat Warszawski wymienił drewniane bale na dolnym poziomie starego mostu i w lipcu 1910 roku uruchomił ruch kołowy. Ponad 10 lat poruszały się po nim furmanki i odbywał się ruch pieszy, podczas gdy górny poziom nie był użytkowany. W czasie I wojny światowej latem 1915 siły niemieckie zbliżyły się do Warszawy. Na polecenie Rosjan 2 sierpnia 1915 wszystkie mosty na Wiśle zostały zaminowane. 5 sierpnia, koło godz. 7., oba mosty przy Cytadeli wysadzono. W starszym moście zniszczono drugi filar od strony lewego brzegu i dźwigar następnego przęsła. W rezultacie uszkodzono trzy przęsła. W nowym moście wysadzono czwarty i szósty filar od lewego brzegu. Zsunęły się do wody przęsła trzecie i czwarte. Przęsła piąte i szóste pozostały jednym końcem z nieznacznymi przesunięciami na filarach. Każdy tor miał swoją parę dźwigarów opartych na wspólnych filarach, w związku z czym uszkodzenia w obu torach były takie same. Niemcy podjęli decyzję odbudowie mostów z własnych środków. Prace budowlane rozpoczęły się 8 sierpnia i miały charakter tymczasowy. Jako pierwszy przywrócono do stanu używalności północny tor nowszego mostu. Przęsła trzecie 
i czwarte podniesiono na wysokość powyżej wysokiej wody i oparto je na jarzmach. Przęsła piąte i szóste podniesiono do pierwotnej wysokości i oparto je na klatkach. Dla uzyskania jednakowego poziomu części przejazdowej na całej długości, na przęsłach trzecim i czwartym zbudowano drewnianą konstrukcję o wysokości $3 \mathrm{~m}$. 1 września tego samego roku po odbudowanym torze przejechał na pierwszy pociąg. Analogicznie tymczasowo odbudowano tor południowy, który powrócił do eksploatacji 17 września. Do 1 października trwały jeszcze prace wykończeniowe.

Niemcy odbudowali też tymczasowo starszy most, by wykorzystać go jako zastępczy. Nie usunięto z rzeki zniszczonych przęseł, lecz wbijano pale pomiędzy ich elementy. Podpory rozstawione były nieregularnie. Trzy zniszczone przęsła zastąpiono 12 blachownicowymi dźwigarami na drewnianych jarzmach. Prace ukończono 23 września 1915.

W późniejszym czasie podjęto decyzję o stałej odbudowie obu mostów. Prace przy południowym torze nowszego mostu trwały od 30 września 1915 do 22 stycznia 1916. Odbudowa stała toru północnego zakończyła się 19 lutego 1916. Odbudowa starszego mostu rozpoczęła się zaraz po zakończeniu prac przy nowszym moście i zakończyła w kwietniu 1916. W miejsce zniszczonych przęseł wbudowano nową konstrukcję składającą się z dźwigarów takich samych, jak w moście nowszym. W czasie wojny polsko-bolszewickiej latem 1920 roku most został przebudowany, aby umożliwić polskiemu wojsku ewakuację przez Wisłę. W ciągu 10 dni tor kolejowy na górnym poziomie został rozebrany, a w jego miejsce powstał drewniany pomost.

Mosty zostały uszkodzone w czasie kampanii wrześniowej 1939. Starszy most miał 21 dużych uszkodzeń w konstrukcji stalowej, a także w chodnikach i balustradach. Został on wyremontowany przez okupanta, a w latach 1940-1941 przerobiony z powrotem na kolejowy. Wbudowano wówczas poprzeczne krzyżulce pomiędzy poziomami, w rezultacie czego nie był już możliwy ruch pieszy. Nowszy most został także uszkodzony w 1939 i wyremontowany przez Niemców. Po wybuchu Powstania Warszawskiego Niemcy zablokowali wszystkie mosty w mieście uniemożliwiając komunikację. 13 września 1944 wysadzili wszystkie warszawskie przeprawy. Po zajęciu Warszawy przez wojska radzieckie rozpoczęła się budowa tymczasowych mostów przez Wisłę. 18 stycznia 1945 roku, Sowieci rozpoczęli budowę tymczasowego mostu kolejowego około 25 m powyżej wysadzonych mostów. Przeprawa składała się z 18 kratownic stalowych z jezdnią górną o rozpiętości $23 \mathrm{~m}$ oraz 2 przęseł brzegowych, blachownicowych o rozpiętości $10 \mathrm{~m}$. Całkowita długość mostu wynosiła 515,70 m, a wysokość - 14,50 m. Przęsła w formie kratownic były przewożone na budowę w całości, gdzie ustawiane były na jarzmach. Most otwarto 29 stycznia 1945. W 1947 został uszkodzony przez powódź, po czym rozebrany.

Odbudowa mostu kolejowego z 1908 roku odbywała się dwuetapowo. Najpierw naprawiono tor północny, odbudowując konstrukcję ze szczątków zwalonego mostu. Dla toru południowego zaprojektowano nowe dźwigary o takiej samej siatce, jak dźwigary północne, tylko spawane. Montaż rozpoczął się wiosną 1946, a otwarcia dokonano 22 lipca.

W 1963 roku wykonane zostało wzmocnienie sprawów w pasach dolnych południowej pary dźwigarów mostu pod Cytadelą. W 1980 roku rozpoczęła się wymiana przęseł północnego toru mostu. Stal konstrukcji była już skorodowana, w dodatku znacząco wzrosły obciążenia. Zachowano geometrię kraty, ale zastosowano zamknięte przekroje prętów, a w węzłach spawanie czołowe. Dzięki zastosowaniu stali St 3M i St 35. W rezultacie udało się zmniejszyć ciężar przęseł. W 2015 roku rozpoczęła się modernizacja mostu mająca na celu zwiększenie dopuszczalnych prędkości i obciążeń poruszających się po nim pociągów. Do 2016 roku odnowiono tor północny. Z powodu złego stanu konstrukcji toru południowego prac nie kontynuowano i podjęto decyzję o jej wymianie. W 2018 podpisana została umowa na modernizację toru południowego. Prace przewidywały wymianę dziewięciu przęseł konstrucji o długości ponad $508 \mathrm{~m}$ oraz wzmocnienie fundamentów podpór. W rezultacie prac linia kolejowa na moście ma być dostosowana do przejazdu pociągów pasażerskich z prędkością $120 \mathrm{~km} / \mathrm{h}$, a towarowych - $100 \mathrm{~km} / \mathrm{h}$. 